Equity Impacts of Transit Fare Proposals: A Case Study of AC Transit Author(s): Cornelius Nuworsoo, Elizabeth Deakin, and Aaron Golub

Source: Journal of the Transportation Research Forum, Vol. 47, No. 3 (Public Transit Special Issue 2008), pp. 23-43

Published by: Transportation Research Forum

Stable URL: http://www.trforum.org/journal

The Transportation Research Forum, founded in 1958, is an independent, nonprofit organization of transportation professionals who conduct, use, and benefit from research. Its purpose is to provide an impartial meeting ground for carriers, shippers, government officials, consultants, university researchers, suppliers, and others seeking exchange of information and ideas related to both passenger and freight transportation. More information on the Transportation Research Forum can be found on the Web at www.trforum.org. 


\title{
Equity Impacts of Transit Fare Proposals: A Case Study of AC Transit
}

\author{
by Cornelius Nuworsoo, Elizabeth Deakin, and Aaron Golub
}

Faced with budget shortfalls, Oakland's AC Transit proposed five alternative fare structures combining base fare hikes or reductions, eliminating free transfers, and discontinuing passes. Using onboard survey data, we analyzed impacts of proposals on groups of riders, evaluated equity impacts, and estimated potential fare revenues. Policies that eliminated passes or transfers produced dramatically unequal impacts on lower income riders, youth, and minorities. Flat fares were least equitable even with base fare reductions because less affluent riders made more frequent trips and transfers than the more affluent. The most equitable and profitable proposals adjusted existing fare structures.

\section{BACKGROUND}

\section{Introduction}

Transit agencies from time to time must evaluate changes in fares and fare structures. In this paper we present an analysis of one such case. The Alameda-Contra Costa Transit District (AC Transit) is the third-largest public bus system in California, serving 13 cities and adjacent unincorporated areas in Alameda and Contra Costa counties, which lie on the east side of the San Francisco Bay. In March 2005, faced with budget shortfalls, AC Transit put forth five alternative fare policy proposals for public discussion. The goal of the proposals was to raise fare revenues. The proposed structures included combinations of fare hikes, base fare reductions, eliminations of free transfers, and discontinuation of periodic passes. In this paper we assess the impacts of the various fare proposals on different subsets of riders. This breakdown of impacts was used to assess how each proposal would affect different user groups as well as to evaluate how equitable each proposal was. We also estimated the fare revenues that would result from each proposal using alternative estimations of price elasticity, i.e., accounting for likely shifts in ridership due to changes in price.

\section{Pricing and Equity}

While increases in revenues are often the major justification for transit fare changes, public transit agencies are also concerned about the equity of the changes. Here we define equity as "fairness in the distribution of goods and services (among the people in an economy)" (Friedman 2002). In the context of transit fares, equity may be defined as how just pricing is among various constituents of riders. Three possible criteria for setting fares equitably would be as follows:

(a) The benefit criterion asserts that people should pay for services in proportion to the benefits they receive from them. For example, transit passengers might pay more for express services than for slower, multi-stop local services or pay more for direct services than for services requiring a transfer, etc.

(b) The cost criterion asserts that people should be charged for the use of the transit services in proportion to the cost of providing service to them. This is complex to determine for individual riders, but could be partially captured through time-of-day and location-based pricing. 
(c) The ability to pay criterion asserts that people should be charged for the use of transit in proportion to their wealth. While this may be partially achieved by charging lower fares to such groups as the youth, the elderly, and the disabled, there is no guarantee that the actual rider in the group is economically disadvantaged.

Transit fares often stray considerably from all of these criteria. One reason is that equity is not the only criterion for pricing structures. For example, to ease fare collection, many bus services replaced distance and zone based fares with flat fares in the 1970s, a change that made long trips (often made by more affluent travelers) a better deal than shorter trips. Nevertheless, equity remains an important consideration for most operators, particularly as measured by ability to pay.

Judging by the third criterion, therefore, whenever new pricing policies are introduced, it is prudent to ensure that fare increases are not any more onerous on members of disadvantaged groups than others. The objective of this paper is to analyze pricing policy options in terms of this principle.

A large and growing literature addresses the subject of equity (Miller et al. 1970; Rawls 1971; Altshuler 1979; Friedman 2002). Studies have applied the concept of equity to such diverse issues as pricing road congestion (Deakin and Harvey 1996; Litman 1996; Richardson 1998), irrigation and residential water supply (Tsur 1995; Howe 1996; Fauconnier 2004), and public transit. Studies that dealt specifically with equity issues in transit covered: (a) investments (Garcia 1998; Garrett et al. 1999; and Deakin et al. 2002), (b) finance (Taylor 1991; and Wachs 2003), (c) time-of-day pricing (Watkins 1984), and (d) distance-based fares (Ballou et al. 1979).

Community groups also have been known to organize to fight for equity. In Los Angeles, for instance, advocates for bus riders, comprised of mainly minority groups, successfully challenged the transit authority's plans to spend massive sums on a suburban-oriented light rail system while simultaneously cutting bus services in the central city (Garcia 1998).

A few studies have looked at the equity of transit fare policies per se. A 1980 paper by Cervero, Wachs, Berlin, and Gephart investigated new pricing policies proposed by three transit agencies for spring 1980. They found that the proposed fare increases across the board appeared promising in terms of revenue yield, but were more regressive than existing structures, redistributing disproportionately more income away from low-income, transit-dependent users. The analytical method of the study by Cervero et al. bears the closest resemblance to the method employed in this paper.

Deakin and Harvey (1996) articulated the need to be cognizant of the equity implications of fare change policies. They noted,

Transportation price increases are especially a concern for low income people who have a limited ability to "choose" to pay the higher costs and hence would be priced out of routine use of certain high-cost travel options. Higher transportation prices also are a worry for moderate income people, especially those who have little flexibility about when or where they travel and hence might have to devote a larger share of their income to transportation. Equity can also be examined by looking at the distribution of impacts by location in the region (e.g. central city vs. suburbs), by gender of the traveler, by race and ethnicity, and so on.

The Transit Cooperative Highway Research Project Report 94 (TCRP-94 2003) stated the following observations about equity and environmental justice issues in public transit:

(a) Environmental justice initiatives to insure that all population segments receive fair treatment are increasingly affecting transit agencies' consideration of potential fare changes. Such initiatives have resulted in legal challenges to proposed fare increases in several cities; moreover, even where such challenges have not proven successful—or have not actually entered the courts - they have influenced the fare policy decision-making process.

(b) In some cases, equity-based challenges have resulted in modifications to fare proposals or legal restrictions on future changes. In others, they have merely required the agencies to go to great lengths to explain and defend their rationale for raising fares. Moreover, because of 
such challenges, many transit agencies, especially those in other large cities, feel that they must now pay greater attention to equity concerns in considering possible fare changes.

In line with these observations, this paper assesses the impacts of proposed fare change policies on various constituents of riders to determine if proposed fare change proposals were equitable.

\section{Elasticity and User Responses to Fare Changes}

The changes proposed by AC Transit may significantly impact the way riders will use the system. Bus riders' responses to changes in fares and fare structures have been studied extensively (see Pratt et al. 2000 for a summary) and are expressed in terms of elasticity. Elasticity is defined as "the percentage change in the use of a particular transportation service resulting from a 1 percent change in an attribute such as price, trip time, or frequency of service" (Small and Winston 1999). General conclusions from the extensive body of work indicate that overall ridership elasticity with respect to fare changes for bus systems is about -0.40 (Linsalata et al. 1991; Pratt et al. 2000). That sensitivity diminishes with increasing city size, during peak hours, for work related trips, and for seniors and riders who are transit dependent (De Leuw et al. 1979; Pratt et al. 2000).

Approximately 1.5 million people live in AC Transit's 364 square mile service area. Two studies have looked specifically at city size and found fare elasticities of -0.24 and -0.36 for the largest urban areas (Mayworm et al. 1980; Linsalata et al. 1991). Fare elasticities for poorer riders are not well understood because of the confounding issues of transit dependency (Pratt et al. 2000). Studies of fare elasticity based on automobile ownership show that autoless riders have markedly lower fare elasticities (De Leuw et al. 1979a and 1979b). Youth were found to have higher sensitivity to fares, presumably because of lower incomes (Mayworm et al. 1980).

The proposed elimination of unlimited use monthly passes would also have significant impacts on ridership. Besides the cost savings for riders making more trips than the number needed to "break even," passes afford other conveniences riders find valuable. A survey of riders in Atlanta found that "Convenience/No need for cash" and "Easier to transfer" were common reasons given, besides cost savings, for purchasing monthly passes (Parody 1982).

\section{THE FARE POLICY PROPOSALS}

The proposed alternatives for fare structures are compared with the existing fare structure in Table 1 and are outlined as follows:

\section{Proposal 1: "Pay per ride"}

(a) Lower base, single-boarding fares

(b) Eliminate pre-paid tickets and passes except monthly passes for seniors and the disabled

(c) Eliminate transfers; passengers would pay full fare at each boarding

Proposal 2: "Raise fares and transfer fees"

(a) Raise fares in all categories except for senior, disabled, and youth monthly passes

(b) Raise the fee for transfers from $\$ 0.25$ to $\$ 0.50$

Proposal 3: "Raise fares with two free transfers"

(a) Raise fares in all categories except for senior, disabled, and youth monthly passes

(b) Free, two-boarding transfers (with payment of fare) that would be valid for 1.5 hours

Proposal 4: "Retain existing structure and add weekly pass"

(a) Retain all current fares and transfer fees

(b) Introduce a weekly, unlimited-ride pass

Proposal 5: "Proposal \#1 but retain youth pass"

(a) Lower cash fares

(b) Eliminate pre-paid tickets and adult monthly passes, but retain monthly passes for seniors, the disabled, and youth

(c) Eliminate transfers; passengers would pay full fare at each boarding 
Transit Fare Proposals

Table 1: Existing Fare Structure and Five Fare Change Proposals

\begin{tabular}{|c|c|c|c|c|c|c|}
\hline & Existing & Proposal 1 & Proposal 2 & Proposal 3 & Proposal 4 & Proposal 5 \\
\hline \multicolumn{7}{|l|}{$\overline{\text { Cash }}$} \\
\hline Local Adult & $\$ 1.50$ & $\$ 1.00$ & $\$ 1.75$ & $\$ 2.00$ & $\$ 1.50$ & $\$ 1.00$ \\
\hline \multirow{2}{*}{$\begin{array}{l}\text { Local Youth } \\
\text { Local Senior/ } \\
\text { Disabled }\end{array}$} & $\$ 0.75$ & $\$ 0.50$ & $\$ 0.85$ & $\$ 1.00$ & $\$ 0.75$ & $\$ 0.50$ \\
\hline & $\$ 0.75$ & $\$ 0.50$ & $\$ 0.85$ & $\$ 1.00$ & $\$ 0.75$ & $\$ 0.50$ \\
\hline Transbay Adult & $\$ 3.00$ & $\$ 2.00$ & $\$ 3.50$ & $\$ 4.00$ & $\$ 3.00$ & $\$ 2.00$ \\
\hline Transbay Youth & $\$ 1.50$ & $\$ 1.00$ & $\$ 1.70$ & $\$ 2.00$ & $\$ 1.50$ & $\$ 1.00$ \\
\hline $\begin{array}{l}\text { Transbay Senior/ } \\
\text { Disabled }\end{array}$ & $\$ 1.50$ & $\$ 1.00$ & $\$ 1.70$ & $\$ 2.00$ & $\$ 1.50$ & $\$ 1.00$ \\
\hline \multicolumn{7}{|c|}{ 31-Day Ticket/ Monthly Pass } \\
\hline Local Adult & $\$ 60.00$ & --- & $\$ 70.00$ & $\$ 70.00$ & $\$ 60.00$ & --- \\
\hline Local Youth & $\$ 15.00$ & --- & $\$ 15.00$ & $\$ 15.00$ & $\$ 15.00$ & $\$ 15.00$ \\
\hline $\begin{array}{l}\text { Local Senior/ } \\
\text { Disabled }\end{array}$ & $\$ 20.00$ & $\$ 20.00$ & $\$ 20.00$ & $\$ 20.00$ & $\$ 20.00$ & $\$ 20.00$ \\
\hline Transbay Adult & $\$ 100.00$ & --- & $\$ 116.00$ & $\$ 116.00$ & $\$ 100.00$ & --- \\
\hline \multicolumn{7}{|l|}{ 10-Ride Ticket } \\
\hline Local Adult & $\$ 15.00$ & --- & $\$ 17.50$ & $\$ 20.00$ & $\$ 15.00$ & --- \\
\hline $\begin{array}{l}\text { Local Youth/ } \\
\text { Senior/Disabled }\end{array}$ & $\$ 7.50$ & --- & $\$ 8.50$ & $\$ 10.00$ & $\$ 7.50$ & --- \\
\hline Transbay Adult & $\$ 30.00$ & --- & $\$ 35.00$ & $\$ 40.00$ & $\$ 30.00$ & --- \\
\hline \multicolumn{7}{|l|}{ Weekly Pass } \\
\hline Local Adult & --- & --- & --- & --- & $\$ 20.00$ & --- \\
\hline $\begin{array}{l}\text { Local Youth/ } \\
\text { Senior/Disabled }\end{array}$ & --- & --- & --- & --- & $\$ 10.00$ & --- \\
\hline Transbay Adult & --- & --- & --- & --- & $\$ 35.00$ & --- \\
\hline \multicolumn{7}{|l|}{ Local Transfer } \\
\hline $1.5 \mathrm{hrs} / 1$ use & $\$ 0.25$ & --- & $\$ 0.50$ & --- & $\$ 0.25$ & --- \\
\hline $1.5 \mathrm{hrs} / 2$ uses & --- & --- & --- & $\begin{array}{l}\text { Free w/ } \\
\text { local fare }\end{array}$ & --- & --- \\
\hline \multicolumn{7}{|c|}{ Transbay Transfer } \\
\hline $1.5 \mathrm{hrs} / 1$ use & $\begin{array}{c}\text { Free } \mathrm{w} / \\
\text { transbay fare }\end{array}$ & --- & $\begin{array}{l}\text { Free } \mathrm{w} / \\
\text { transbay fare }\end{array}$ & --- & $\begin{array}{c}\text { Free w/ } \\
\text { Transbay fare }\end{array}$ & --- \\
\hline $1.5 \mathrm{hrs} / 2$ uses & --- & --- & --- & $\begin{array}{c}\text { Free w/transbay } \\
\text { fare }\end{array}$ & --- & --- \\
\hline
\end{tabular}

Source: www.ACTransit.org; retrieved March 10, 2005. 
The fare proposals were not intended to affect such group pass programs as the City of Berkeley ECO Pass and the University of California Student Class Pass. These programs are therefore excluded from the analysis.

\section{PROFILE OF RIDERS}

To determine whether various fare proposals could differentially affect subsets of riders, we first prepared profiles of AC Transit riders using the agency's 2002 on-board surveys. The rider characteristics summarized here were selected to conform with items most relevant to the analysis. Rider profiles are therefore outlined in terms of: (a) local versus transbay travel, (b) number of boardings on one-way trips, (c) payment type, and (d) fare groups. These characteristics are compared by gender, income group, and race. Table 2 summarizes the distribution of riders by these characteristics.

Table 2: Profile of AC Transit Riders

\begin{tabular}{|c|c|c|c|}
\hline & \multicolumn{3}{|c|}{ a. Local vs. Transbay Travel } \\
\hline & Local & Transbay & Total \\
\hline & \multicolumn{3}{|c|}{ By Gender } \\
\hline Male & $94 \%$ & $6 \%$ & $100 \%$ \\
\hline Female & $93 \%$ & $7 \%$ & $100 \%$ \\
\hline \multirow[t]{2}{*}{ All Valid Responses } & $93 \%$ & $7 \%$ & $100 \%$ \\
\hline & \multicolumn{3}{|c|}{ Income Group } \\
\hline Under $\$ 10,000$ & $99 \%$ & $1 \%$ & $100 \%$ \\
\hline$\$ 10,000-\$ 29,999$ & $98 \%$ & $2 \%$ & $100 \%$ \\
\hline$\$ 30,000-\$ 49,999$ & $92 \%$ & $8 \%$ & $100 \%$ \\
\hline$\$ 50,000-\$ 74,999$ & $83 \%$ & $17 \%$ & $100 \%$ \\
\hline$\$ 75,000-\$ 100,000$ & $72 \%$ & $28 \%$ & $100 \%$ \\
\hline Over $\$ 100,000$ & $60 \%$ & $40 \%$ & $100 \%$ \\
\hline Do Not Know & $99 \%$ & $1 \%$ & $100 \%$ \\
\hline \multirow[t]{2}{*}{ All Valid Responses } & $93 \%$ & $7 \%$ & $100 \%$ \\
\hline & \multicolumn{3}{|c|}{ By Race } \\
\hline Asian/Pacific Islander & $91 \%$ & $9 \%$ & $100 \%$ \\
\hline Black / African American & $97 \%$ & $3 \%$ & $100 \%$ \\
\hline Native American Indian & $97 \%$ & $3 \%$ & $100 \%$ \\
\hline White & $85 \%$ & $15 \%$ & $100 \%$ \\
\hline Hispanic/Latino & $97 \%$ & $3 \%$ & $100 \%$ \\
\hline Other & $98 \%$ & $2 \%$ & $100 \%$ \\
\hline All Valid Responses & $94 \%$ & $6 \%$ & $100 \%$ \\
\hline
\end{tabular}


Table 2: Profile of AC Transit Riders (continued)

\begin{tabular}{|c|c|c|c|c|c|}
\hline \multicolumn{6}{|c|}{ b. Legs on Local One -Way Trip } \\
\hline $\begin{array}{l}1 \text {-- Single } \\
\text { Leg }\end{array}$ & $\begin{array}{l}2 \text {-- Two } \\
\text { Legs }\end{array}$ & $\begin{array}{l}3 \text {-- Three } \\
\text { Legs }\end{array}$ & $\begin{array}{c}4^{+}-- \\
\text {Four Legs plus }\end{array}$ & Total & Average Legs / Trip \\
\hline \multicolumn{6}{|c|}{ By Gender } \\
\hline $45 \%$ & $42 \%$ & $8 \%$ & $5 \%$ & $100 \%$ & 1.73 \\
\hline $44 \%$ & $44 \%$ & $8 \%$ & $5 \%$ & $100 \%$ & 1.74 \\
\hline $44 \%$ & $43 \%$ & $8 \%$ & $5 \%$ & $100 \%$ & 1.74 \\
\hline \multicolumn{6}{|c|}{ Income Group } \\
\hline $35 \%$ & $48 \%$ & $11 \%$ & $6 \%$ & $100 \%$ & 1.88 \\
\hline $41 \%$ & $46 \%$ & $9 \%$ & $4 \%$ & $100 \%$ & 1.76 \\
\hline $52 \%$ & $38 \%$ & $5 \%$ & $4 \%$ & $100 \%$ & 1.61 \\
\hline $53 \%$ & $39 \%$ & $5 \%$ & $3 \%$ & $100 \%$ & 1.58 \\
\hline $58 \%$ & $34 \%$ & $4 \%$ & $4 \%$ & $100 \%$ & 1.55 \\
\hline $59 \%$ & $28 \%$ & $6 \%$ & $6 \%$ & $100 \%$ & 1.61 \\
\hline $45 \%$ & $42 \%$ & $8 \%$ & $5 \%$ & $100 \%$ & 1.73 \\
\hline $45 \%$ & $43 \%$ & $8 \%$ & $5 \%$ & $100 \%$ & 1.73 \\
\hline \multicolumn{6}{|c|}{ By Race } \\
\hline $53 \%$ & $37 \%$ & $6 \%$ & $3 \%$ & $100 \%$ & 1.59 \\
\hline $37 \%$ & $48 \%$ & $10 \%$ & $6 \%$ & $100 \%$ & 1.85 \\
\hline $36 \%$ & $44 \%$ & $11 \%$ & $9 \%$ & $100 \%$ & 1.92 \\
\hline $58 \%$ & $34 \%$ & $5 \%$ & $3 \%$ & $100 \%$ & 1.53 \\
\hline $38 \%$ & $48 \%$ & $9 \%$ & $5 \%$ & $100 \%$ & 1.82 \\
\hline $45 \%$ & $37 \%$ & $10 \%$ & $8 \%$ & $100 \%$ & 1.81 \\
\hline $44 \%$ & $43 \%$ & $8 \%$ & $5 \%$ & $100 \%$ & 1.74 \\
\hline
\end{tabular}

\section{Local vs. Transbay Trips}

Of AC Transit bus trips, $93 \%$ are local and $7 \%$ are transbay. Transbay travelers are significantly different than local travelers as follows:

By Gender: The distribution of trips between local and transbay travel is the same by gender. However, there are approximately $10 \%$ more female riders than male riders on AC Transit.

By Income Group: Riders in upper income groups conduct significantly more cross-bay travel (at $17 \%$ to $40 \%$ ) than the overall average of $7 \%$. Low-income riders conduct only $3 \%$ of their trips across the bay.

By Race: At $15 \%$ and $9 \%$ respectively, whites and Asians conduct significantly more travel across the bay than other racial groups. 
Table 2: Profile of AC Transit Riders (continued)

\begin{tabular}{|c|c|c|c|c|}
\hline \multirow[b]{4}{*}{ Male } & \multicolumn{4}{|c|}{ c. Payment Type } \\
\hline & Cash & $\begin{array}{c}\text { Prepaid } \\
\text { Ticket }\end{array}$ & Pass & Total \\
\hline & \multicolumn{4}{|c|}{ By Gender } \\
\hline & $49 \%$ & $7 \%$ & $44 \%$ & $100 \%$ \\
\hline Female & $44 \%$ & $9 \%$ & $47 \%$ & $100 \%$ \\
\hline \multirow[t]{2}{*}{ All Valid Responses } & $46 \%$ & $8 \%$ & $46 \%$ & $100 \%$ \\
\hline & \multicolumn{4}{|c|}{ By Income Group } \\
\hline Under $\$ 10,000$ & $46 \%$ & $8 \%$ & $46 \%$ & $100 \%$ \\
\hline$\$ 10,000-\$ 29,999$ & $49 \%$ & $8 \%$ & $44 \%$ & $100 \%$ \\
\hline$\$ 30,000-\$ 49,999$ & $51 \%$ & $8 \%$ & $40 \%$ & $100 \%$ \\
\hline$\$ 50,000-\$ 74,999$ & $51 \%$ & $10 \%$ & $38 \%$ & $100 \%$ \\
\hline$\$ 75,000-\$ 100,000$ & $49 \%$ & $13 \%$ & $38 \%$ & $100 \%$ \\
\hline Over $\$ 100,000$ & $46 \%$ & $13 \%$ & $41 \%$ & $100 \%$ \\
\hline Do Not Know & $39 \%$ & $7 \%$ & $54 \%$ & $100 \%$ \\
\hline \multirow[t]{2}{*}{ All Valid Responses } & $46 \%$ & $8 \%$ & $46 \%$ & $100 \%$ \\
\hline & \multicolumn{4}{|c|}{ By Race } \\
\hline Asian/Pacific Islander & $34 \%$ & $14 \%$ & $52 \%$ & $100 \%$ \\
\hline Black / African American & $42 \%$ & $6 \%$ & $51 \%$ & $100 \%$ \\
\hline Native American Indian & $44 \%$ & $4 \%$ & $51 \%$ & $100 \%$ \\
\hline White & $43 \%$ & $10 \%$ & $47 \%$ & $100 \%$ \\
\hline Hispanic/Latino & $64 \%$ & $5 \%$ & $31 \%$ & $100 \%$ \\
\hline Other & $44 \%$ & $12 \%$ & $44 \%$ & $100 \%$ \\
\hline All Valid Responses & $46 \%$ & $8 \%$ & $46 \%$ & $100 \%$ \\
\hline
\end{tabular}

\section{Number of Legs on One-Way Local Trips}

By Gender: At about $44 \%$ each, the distribution of trips among one-leg and two-leg travel is the same by gender. The remaining $13 \%$ of all travel on AC transit involve three or more legs.

By Income Group: $60 \%$ to $65 \%$ of low income bus users' one-way trips require two or more boardings. On the contrary, more than half (53\%) of trips by middle to higher income groups require a single boarding.

By Race: Among whites and Asians, more than half, or approximately 55\%, of trips involve a single leg. Members of other racial groups take two or more boardings to complete $55 \%$ to $60 \%$ of their trips.

\section{Payment Type (Local Trips)}

By Gender: The distribution of payment type is the same between those who use cash and those who use passes (at $46 \%$ each). The remaining $8 \%$ of trips on AC transit are paid for with the 10-pack ticket. The shares are quite similar by gender. 
Transit Fare Proposals

Table 2: Profile of AC Transit Riders (continued)

\begin{tabular}{|c|c|c|c|c|}
\hline \multicolumn{5}{|c|}{ d. Fare Group } \\
\hline Youth & Senior & Adult & Disabled & Total \\
\hline \multicolumn{5}{|c|}{ By Gender } \\
\hline $23 \%$ & $6 \%$ & $65 \%$ & $7 \%$ & $100 \%$ \\
\hline $24 \%$ & $6 \%$ & $66 \%$ & $5 \%$ & $100 \%$ \\
\hline $23 \%$ & $6 \%$ & $65 \%$ & $6 \%$ & $100 \%$ \\
\hline \multicolumn{5}{|c|}{ By Income Group } \\
\hline $13 \%$ & $7 \%$ & $67 \%$ & $12 \%$ & $100 \%$ \\
\hline $9 \%$ & $7 \%$ & $77 \%$ & $7 \%$ & $100 \%$ \\
\hline $10 \%$ & $4 \%$ & $83 \%$ & $3 \%$ & $100 \%$ \\
\hline $14 \%$ & $4 \%$ & $79 \%$ & $3 \%$ & $100 \%$ \\
\hline $15 \%$ & $5 \%$ & $78 \%$ & $3 \%$ & $100 \%$ \\
\hline $26 \%$ & $5 \%$ & $68 \%$ & $1 \%$ & $100 \%$ \\
\hline $57 \%$ & $2 \%$ & $38 \%$ & $3 \%$ & $100 \%$ \\
\hline $23 \%$ & $5 \%$ & $66 \%$ & $6 \%$ & $100 \%$ \\
\hline \multicolumn{5}{|c|}{ By Race } \\
\hline $20 \%$ & $11 \%$ & $68 \%$ & $2 \%$ & $100 \%$ \\
\hline $32 \%$ & $3 \%$ & $58 \%$ & $8 \%$ & $100 \%$ \\
\hline $30 \%$ & $3 \%$ & $59 \%$ & $8 \%$ & $100 \%$ \\
\hline $15 \%$ & $8 \%$ & $69 \%$ & $8 \%$ & $100 \%$ \\
\hline $24 \%$ & $3 \%$ & $71 \%$ & $2 \%$ & $100 \%$ \\
\hline $24 \%$ & $6 \%$ & $61 \%$ & $10 \%$ & $100 \%$ \\
\hline $25 \%$ & $5 \%$ & $64 \%$ & $6 \%$ & $100 \%$ \\
\hline
\end{tabular}

e. Distribution of Single and Multiple Leg Trips by Fare Category

\begin{tabular}{cccccc}
\hline & Youth & Senior & Adult & Disabled & All \\
\cline { 2 - 6 } Single Leg Trips & $44 \%$ & $39 \%$ & $50 \%$ & $32 \%$ & $47 \%$ \\
Multiple Leg Trips & $56 \%$ & $61 \%$ & $50 \%$ & $68 \%$ & $53 \%$ \\
\hline
\end{tabular}

Source: Compiled from 2002 AC Transit Onboard Survey Data. 
By Income Group: Payment by both cash and its variant, the 10-pack ticket, increases slightly with increase in income.

By Race: Slightly more than half of rides by the minority groups of Asian, African, and Native American descent entail use of the pass followed closely by cash payments at above $40 \%$. Among Latinos, cash payments dominate at $64 \%$ of rides. Fare media use by whites mimics the overall distribution.

\section{Fare Group (Local Trips)}

There are three categories of fares: adult, youth, and senior and the disabled. Adults make up twothirds of the ridership, followed by youth at $23 \%$. Seniors and the disabled constitute small, but significant, proportions at $6 \%$ each.

By Gender: The distribution of trips between the fare groups is the same by gender.

By Income Group: Seniors and disabled riders are more likely to fall into the low income brackets than adults. While the majority of youth were not able to identify their household incomes, those who responded indicated a significant proportion in low income groups. Adult riders dominate in all the income groups.

By Race: The distribution of fare groups is quite similar among various racial groups.

\section{FARE POLICY OPTIONS: EVALUATION METHODOLOGY}

\section{Ridership Data and Sample Sizes}

The analysis of fare policy options is based on AC Transit's most recent on-board rider survey, which was conducted in 2002. The database has 15,370 records of linked, one-way trip information and socio-economic characteristics of riders. More than $90 \%$ of the trip data constitutes local travel while the remainder covers transbay trips. "The estimated sampling error for the survey is $\pm 1 \%$ at the 95\% confidence level. This means that we are 95\% confident that all AC Transit riders would produce responses to each survey question within approximately one percentage point of the results obtained from this sample" (Blash et al. 2003). The effects of fare proposals depend upon initial fares and transfer policies, so the analysis was structured as follows:

(a) We separated local travel from transbay travel since different initial fares apply.

(b) Since at the time, only the first transfer is at a discount, we sorted the trips in the database by the number of legs it took to complete a linked, one-way trip. For example, a trip which involves three legs is one where the rider has made two transfers - an initial boarding at a base fare, a transfer onto the second bus at the applicable transfer fee, and a second transfer onto the third bus that could involve another fare payment if cash or the ten-pack ticket were used.

Table 3 describes the sample for the analysis. Part A of the table shows the sample sizes of valid cases and reveals that sample sizes are large enough to support an analysis by number of legs for local travel, but for transbay travel the sample is too small to separately analyze the categories with 3 and 4-plus legs. Therefore, in this paper, our analyses of transbay trips do not consider the number of legs that constitute linked trips.

To identify the effects of individual features of the five fare proposals, the data were further cross classified by the four fare categories: youth, senior, disabled, and adult; and by the three primary fare media: cash, 10-ride ticket, and monthly pass. As noted earlier, the fare proposals do not affect group pass programs, and trips made using these passes were excluded from the analysis. Table 3, parts B and C compare the distributions of sample sizes by these classifications. Sample sizes for transbay trips by some fare categories are too small to be statistically reliable, therefore, analysis of transbay trips was restricted to the classification by fare media. 
Transit Fare Proposals

Table 3: Sample Characteristics

\begin{tabular}{lccccccc}
\hline a. Sample Sizes by Number of Rides per Trip \\
\hline Classification & \multicolumn{7}{c}{$\begin{array}{c}\text { Number of Legs on Linked, } \\
\text { One-Way Trip }\end{array}$} \\
\cline { 2 - 8 } & $\mathbf{1}$ & $\mathbf{2}$ & $\mathbf{3}$ & $\mathbf{4 +}$ & Total & $\begin{array}{c}\text { \% of Valid } \\
\text { Responses }\end{array}$ & $\begin{array}{c}\text { Average } \\
\text { Number of } \\
\text { Legs }\end{array}$ \\
Local Trips & 4,117 & 4,213 & 780 & 464 & 9,574 & $92 \%$ & 1.75 \\
Transbay Trips & 711 & 127 & $13 *$ & $5 *$ & 856 & $8 \%$ & 1.2 \\
All Trips & 4,828 & 4,340 & 793 & 469 & 10,430 & $100 \%$ & 1.71 \\
Percent of Sample & $46 \%$ & $42 \%$ & $8 \%$ & $4 \%$ & $100 \%$ & & \\
\hline
\end{tabular}

*Sample size too small to support detailed analysis

b. Sample Sizes by Type of Fare

\begin{tabular}{lrrrrrc}
\hline & Youth & Senior & Disabled & Adult & Total & \% of Valid Responses \\
\cline { 2 - 7 } Local Trips & 2,476 & 570 & 642 & 5,887 & 9,574 & $92 \%$ \\
Transbay Trips & $* 10$ & $* 18$ & $* 15$ & 812 & 855 & $8 \%$ \\
All Trips & 2,486 & 588 & 657 & 6,699 & 10,429 & $100 \%$ \\
Percent of Sample & $24 \%$ & $6 \%$ & $6 \%$ & $64 \%$ & $100 \%$ & \\
\hline
\end{tabular}

*Sample size too small to support detailed analysis.

c. Sample Sizes by Type of Payment

\begin{tabular}{lrrrrr}
\hline & Cash & $\begin{array}{c}\mathbf{1 0 -} \\
\text { Ride } \\
\text { Ticket }\end{array}$ & $\begin{array}{c}\text { Monthly } \\
\text { Pass }\end{array}$ & \multicolumn{1}{l}{ Total } & \% of Valid Responses \\
\cline { 2 - 6 } & 4,427 & 777 & 4,370 & 9,574 & $92 \%$ \\
Local Trips & 121 & 280 & 454 & 855 & $8 \%$ \\
Transbay Trips & 4,548 & 1,057 & 4,824 & 10,429 & $100 \%$ \\
All Trips & $44 \%$ & $10 \%$ & $46 \%$ & $100 \%$ & \\
Percent of Sample & & & &
\end{tabular}

By using the 2002 Rider Survey to represent the AC Transit market and sub-markets, we essentially assumed that market shares and traveler characteristics in each submarket remained the same as the time the survey was conducted. Some changes in overall ridership have certainly occurred. Nevertheless, in our view, the 2002 Rider Survey is the best, most recent, and most complete dataset describing user trips by all of the different fare media and categories. While the demographics of users in particular fare and payment categories might have changed in the previous three years, it is doubtful that they have changed enough with respect to each other to make the inter-category comparisons made here invalid. Finally, the methodology used here should be robust; if additional, more recent data become available, they could easily be used to update the data used here, thus, to update the findings.

\section{Assessing Impact on Rider Expenditure}

The crux of the analysis involved the calculation of average costs of linked one-way trips for subsets of patrons depending on the fare category and type of payment used. The assumptions and procedure are outlined as follows: 
(a) All data in the database were weighted to reflect system-wide usage at the time of the survey.

(b) Each trip in the database was assigned a base fare, which depended on the following:

1. Whether the trip was local or transbay

2. What type of fare category the respondent belonged to

3. What type of fare media the respondent used.

(c) The odd-numbered legs of one-way trips (i.e., first and third legs) were assigned base fares while even-numbered legs (i.e., second and fourth legs) were treated as transfers. For Proposal \#3, the second and third legs were considered transfers where applicable. See Table 1 for fare structures.

(d) The base fares and transfer fees were summed to arrive at the cost of each linked, one-way trip.

(e) The mean costs of one-way trips were calculated for the user groups of interest (youth, seniors, disabled, adult, by income, etc)

(f) The procedure was repeated for the existing fare structure and the five proposed fare structures.

(g) The differences in costs of one-way trips between existing and proposed fare structures were compared to determine the impacts on riders.

\section{Assessing Impact on Agency Revenues}

Since the proposals were put forward primarily to generate increased revenues, we continued with a comparative study of the effects of the fare changes on agency revenues. The revenues were calculated by multiplying expected (average) fares and the ridership for each individual group. The most current ridership numbers for each category were the 2003 boardings reported to the National Transit Database (NTD).

Initially, revenues were calculated with ridership at the existing (2002) level. This is essentially an assumption that there would be the same distribution of users with the same distribution of payment types under the new proposals as in the existing case.

More realistically, both ridership and its distribution among users and fare types are likely to change as price structures are altered. Some users will decide not to travel at all, or will change the way they travel. Riders who currently make many transfers might decide to take alternatives like rail (BART), or drive or walk for part of their trip if they must pay for each leg of their travel. Others who use a pass to make many trips might make fewer trips if passes are discontinued. Riders who now pay cash might decide to ride more if cash fares go down under new proposals. Some riders will be more sensitive to price changes than others depending on demographics, such as income or age; rider sensitivity to price also depends on trip purpose, e.g., riders going to work will be less sensitive to price than riders making discretionary trips. To reflect these likely changes in ridership after the fare changes, the revenue estimates were refined to consider the effects of price elasticities on ridership. The elasticity values we used in this analysis were based on a comprehensive national study (TCRP-B-12, 2000) and are discussed in more detail in the results section which follows.

\section{RESULTS}

\section{Ridership Patterns}

The effects of fare proposals depend on the initial fare, the charge for transfers, and the presence and pricing of passes and 10-ride tickets. Table 2 shows the splits between one-leg and multiple-leg trips among the four key types of payment for combined local and transbay travel. System-wide, slightly more than half of AC Transit patrons take two or more boardings to complete each one-way 
trip. These riders are of somewhat lower income than the average patron and are more likely to be members of ethnic or racial minority groups.

\section{Impacts of Fare Changes on Riders}

With a preponderance of multiple-leg trips, fare policies that either increase the cost of transfers or reduce the availability of unlimited-use passes create dramatically unequal levels of impacts on different groups of patrons, who use AC Transit differently. The unequal rate of transfers exhibited by different groups means the elimination of discounted transfers will have an unequal fare increase on these different groups. Youth and senior users transfer more often than adult users, therefore, are impacted more. The analysis is structured to produce results by the various categories of fare and payment types, income levels, ethnic and racial categories, and other demographics.

Parts A and B of Table 4 compare levels of impacts of the fare proposals on several constituents of AC Transit riders under two assumptions for the level of pass use. The following discussion refers to the higher level of pass use (Table 4a), considered close to typical.

\section{Impacts of Proposal 1: "Pay per ride” and Proposal 5: "Proposal 1 but retain youth pass"}

Proposals 1 and 5, which eliminate passes and transfers, have the least favorable impacts for patrons who transfer often. Fares rise $20 \%$ overall, and the impacts are highly regressive, with poorer patrons facing up to a $34 \%$ fare hike while those earning more than $\$ 100,000$ experience only a $9 \%$ increase. Former pass holders would experience the largest overall fare increases, with a $128 \%$ increase; youth would be close behind with an $82 \%$ increase in fares. Native and African American riders would see a $31 \%$ average fare increase versus a $9 \%$ increase for Caucasian riders. The impacts, therefore, will be disproportionately higher on youth, low-income earners, and minority groups in comparison with the general impact on all patrons.

\section{Impacts of Proposal 2: "Raise fares and transfer fees"}

Proposal 2 is similar to Proposal 3, but involves a lower fare hike and includes a transfer fee hike. Across most subgroups, the distribution of impacts is fairly flat. Differential impacts occur for riders who make multiple-leg trips. The overall fare increase is roughly $13 \%$. The poorest riders see an increase of $12 \%$ while the wealthiest groups experience a $15 \%$ average increase.

\section{Impacts of Proposal 3: "Raise fares with free transfers"}

The two-free-transfer feature of Proposal 3 renders it the most favorable alternative proposal from an equity perspective, despite that it also features the highest base fare hike. It is neutral or slightly progressive in its impacts across income groups, with the poorest riders seeing a $6 \%$ increase in average fares while fares for the wealthiest riders go up $17 \%$ on average. The overall increase for all riders is $11 \%$. Riders who make multiple transfers, many of whom are also low income and minority, fare better under these fares than with other proposals. The segments of riders most severely impacted are single-ride local trip makers and transbay travelers. However, the impact would affect fare categories relatively uniformly.

\section{Impacts of Proposal 4: "Retain existing structure and add weekly pass”}

Proposal 4 is nearly the same as the existing fare structure and a straightforward analysis does not indicate any real differences. Because the weekly pass is a new option, we analyzed this proposal to see what the effects would be if weekly passes were to replace the 10-ride ticket. Results show favorable impacts on the group of riders who currently use the 10-ride ticket since they would spend 
Table 4: Changes in Response to Fare Policy Options

a) Percent Changes in One-Way Fares for Selected Constituents (Local Trips) for Pass Use at 80 Bus Rides per Month

\begin{tabular}{|c|c|c|c|c|c|}
\hline \multirow[b]{2}{*}{ Constituents } & \multicolumn{5}{|c|}{ Fare Change (Percent) } \\
\hline & $\begin{array}{c}\text { Proposal } \\
1\end{array}$ & $\begin{array}{c}\text { Proposal } \\
2\end{array}$ & $\begin{array}{c}\text { Proposal } \\
3\end{array}$ & $\begin{array}{c}\text { Proposal } \\
4\end{array}$ & $\begin{array}{c}\text { Proposal } \\
5\end{array}$ \\
\hline \multicolumn{6}{|l|}{ System-wide Average: } \\
\hline All patrons & +20 & +13 & +11 & -3 & +10 \\
\hline \multicolumn{6}{|l|}{ Fare Class: } \\
\hline Youth & +82 & +12 & +3 & -4 & -10 \\
\hline Senior & -9 & 10 & 3 & -6 & -9 \\
\hline Disabled & -5 & 1 & -6 & -3 & -5 \\
\hline Adult & 14 & 13 & 13 & -3 & 14 \\
\hline \multicolumn{6}{|l|}{ Payment Type: } \\
\hline Cash & -7 & 16 & 13 & 0 & -7 \\
\hline Prepaid Ticket & -11 & 17 & 13 & -30 & -11 \\
\hline Monthly pass users & +128 & -1 & +4 & 0 & +78 \\
\hline \multicolumn{6}{|l|}{ Income: } \\
\hline CalWORKS participants & +34 & +9 & +6 & -3 & +25 \\
\hline Income under $\$ 10,000$ & +22 & +10 & +6 & -3 & +17 \\
\hline Income $\$ 10,000$ to $\$ 29,999$ & +20 & +13 & +9 & -3 & +17 \\
\hline Income $\$ 30,000$ to $\$ 49,999$ & 12 & 15 & 16 & -3 & 9 \\
\hline Income $\$ 50,000$ to $\$ 74,999$ & 10 & 16 & 18 & -4 & 7 \\
\hline Income $\$ 75,000$ to $\$ 99,999$ & 7 & 15 & 17 & -5 & 0 \\
\hline Income $\$ 100,000$ plus & 9 & 12 & 16 & -6 & -3 \\
\hline \multicolumn{6}{|l|}{ Race: } \\
\hline Asian/Pacific Islander & +21 & +13 & +15 & -7 & +13 \\
\hline Black / African American & +30 & +12 & +8 & -3 & +15 \\
\hline Native American Indian & +31 & +9 & +8 & -2 & +15 \\
\hline White & +9 & +15 & +17 & -4 & +3 \\
\hline Hispanic/Latino & +14 & +13 & +10 & -2 & +7 \\
\hline Other & +16 & +10 & +10 & -5 & +5 \\
\hline
\end{tabular}

$\mathbf{0 0}$ - impact higher than system-wide average

similar amounts as under existing fares, but enjoy free transfers because of the pass. Fares for almost all rider groups would, therefore, go down under this proposal if 10-ride ticket holders convert to weekly passes. The introduction of unlimited-ride weekly passes would, thus, constitute another source of convenience for the riding public, but at the cost of revenue for AC Transit.

\section{Analysis of Fare Impacts on a Typical One-way Trip}

Available data did not include the typical numbers of trips made by various pass users from which to estimate their average cost per one-way trip. We addressed this data deficiency by analyzing a range of possible usage levels. At the low end, we assumed the typical monthly pass user made 40 trips a 
Transit Fare Proposals

Table 4: Changes in Response to Fare Policy Options (continued)

b) Percent Changes in One-Way Fares for Selected Constituents (Local Trips) for Pass Use at 40 Bus Rides per Month

\begin{tabular}{|c|c|c|c|c|c|}
\hline \multirow[b]{2}{*}{ Constituents } & \multicolumn{5}{|c|}{ Fare Change (Percent) } \\
\hline & $\begin{array}{c}\text { Proposal } \\
1 \\
\end{array}$ & $\begin{array}{c}\text { Proposal } \\
2 \\
\end{array}$ & $\begin{array}{c}\text { Proposal } \\
3 \\
\end{array}$ & $\begin{array}{c}\text { Proposal } \\
4 \\
\end{array}$ & $\begin{array}{c}\text { Proposal } \\
5 \\
\end{array}$ \\
\hline \multicolumn{6}{|l|}{ System-wide Average: } \\
\hline All patrons & +4 & +21 & +9 & -3 & -1 \\
\hline \multicolumn{6}{|l|}{ Fare Class: } \\
\hline Youth & +41 & +15 & -1 & -3 & -6 \\
\hline Senior & -5 & +15 & -2 & -4 & -5 \\
\hline Disabled & -2 & +9 & -8 & -2 & -2 \\
\hline Adult & 0 & +22 & +11 & -3 & 0 \\
\hline \multicolumn{6}{|l|}{ Payment Type: } \\
\hline Cash & -7 & +24 & +13 & 0 & -7 \\
\hline Prepaid Ticket & -11 & +23 & +13 & -30 & -11 \\
\hline Monthly pass users & +20 & +12 & +4 & 0 & +3 \\
\hline \multicolumn{6}{|l|}{ Income: } \\
\hline CalWORKS participants & +10 & +21 & +4 & -3 & +5 \\
\hline Income under $\$ 10,000$ & +7 & +21 & +4 & -3 & +4 \\
\hline Income $\$ 10,000$ to $\$ 29,999$ & +4 & +21 & +7 & -2 & +2 \\
\hline Income $\$ 30,000$ to $\$ 49,999$ & -3 & +21 & +13 & -3 & -5 \\
\hline Income $\$ 50,000$ to $\$ 74,999$ & -5 & +20 & +15 & -3 & -7 \\
\hline Income $\$ 75,000$ to $\$ 99,999$ & -5 & +20 & +15 & -4 & -9 \\
\hline Income $\$ 100,000$ plus & -3 & +19 & +14 & -5 & -10 \\
\hline \multicolumn{6}{|l|}{ Race: } \\
\hline Asian/Pacific Islander & +1 & +19 & +12 & -5 & -3 \\
\hline Black / African American & +9 & +20 & +6 & -2 & 0 \\
\hline Native American Indian & +9 & +20 & +6 & -2 & 0 \\
\hline White & -4 & +19 & +15 & -4 & -8 \\
\hline Hispanic/Latino & +7 & +23 & +7 & -1 & +2 \\
\hline Other & +3 & +20 & +7 & -4 & -3 \\
\hline
\end{tabular}

$\mathbf{0 0}$ - impact higher than system-wide average

month for the adult, breakeven price of $\$ 1.50$ per trip. At the high end, we assumed a pass user made twice as many (80) trips a month for an adult fare of $\$ 0.75$ per trip.

Table 5 compares the estimated average costs of one-way local trips considering the various differential fares and transfer fees under existing and proposed fare policies. The following impacts are noteworthy:

- The fewer the number of trips made by monthly pass users, the lower will be the impact on riders of the pay-per-boarding Proposals 1 and 5.

- For Proposal 2, which maintains the existing structure but hikes fares and transfer fees, the fewer the number of trips made by pass users, and the higher are its impacts on subsets of riders. 
- Since Proposal 3 combines the existing structure with fare hikes and two free transfers, the fewer the number of trips made by monthly pass users, and the lower will be its impacts on riders. However, the range of impacts is narrower than for Proposals 1, 2, and 5.

Table 5: Mean Cost of One-Way Local Trips by Fare Change Policy (All Groups of Riders)

\begin{tabular}{|c|c|c|c|c|c|c|}
\hline & Existing & $\begin{array}{c}\text { Proposal } \\
1\end{array}$ & $\begin{array}{c}\text { Proposal } \\
2\end{array}$ & $\begin{array}{c}\text { Proposal } \\
3\end{array}$ & $\begin{array}{c}\text { Proposal } \\
4\end{array}$ & $\begin{array}{c}\text { Proposal } \\
5\end{array}$ \\
\hline \multicolumn{7}{|c|}{ Mean Cost of Trip ${ }^{1}$} \\
\hline 80 Trips & $\$ 1.12$ & $\$ 1.34$ & $\$ 1.26$ & $\$ 1.24$ & $\$ 1.08$ & $\$ 1.23$ \\
\hline 40 Trips & $\$ 1.27$ & $\$ 1.32$ & $\$ 1.53$ & $\$ 1.37$ & $\$ 1.23$ & $\$ 1.25$ \\
\hline Difference & $+\$ 0.15$ & $-\$ 0.02$ & $+\$ 0.27$ & $+\$ 0.13$ & $+\$ 0.15$ & $+\$ 0.02$ \\
\hline \multicolumn{7}{|c|}{ Percent Change from Existing } \\
\hline 80 Trips & & $20 \%$ & $13 \%$ & $11 \%$ & $-3 \%$ & $10 \%$ \\
\hline 40 Trips & & $4 \%$ & $21 \%$ & $9 \%$ & $-3 \%$ & $-1 \%$ \\
\hline
\end{tabular}

${ }^{1}$ Mean cost was calculated for all non-pass users depending on number of legs per one-way trip whereas two costs were calculated for pass users to correspond to high and low levels of rides enabling sensitivity analysis of a range of usage levels per month

\section{Price Elasticities and Net Impacts on Fare Revenues}

The responsiveness of AC Transit patrons to changes in the price of service is the elasticity of ridership with respect to price. If ridership is elastic, a rise in fares should be followed by decline in the number of users, and a larger fare increase would cause a larger decline in the number of users. Here, as a rough estimation, two elasticity values are applied across the board to rider groups defined by fare type and payment method. A typical estimate assumes an elasticity of transit ridership with respect to fares of -0.33 (Curtin 1968); a more conservative estimate uses the value of -0.1 . With a $10 \%$ fare increase, if the price elasticity is -0.33 , the ridership decline would be $3.3 \%$; if the elasticity is only -0.1 , a $1 \%$ ridership decline would be likely. The two assumptions are consistent with a relatively price inelastic nature generally associated with public transit.

Table 6 presents the estimated changes to fare revenues by the proposed fare policies under two assumptions for the level of pass use. Since we did not have access to the full accounting data on AC Transit receipts, the estimates are for "changes in fare revenues" only. Administrative cost savings or increases are not included in the analysis.

The top pair of rows reflects the revenue estimates assuming no changes in ridership due to fare changes. The next set of rows shows results using a -0.1 price elasticity. Revenue projections are weaker for all of the proposals as riders are lost from the rise in fares. Using a more typical ridership response to price, the third set of rows shows that many of the revenue increases could turn out to be fairly small. Consistent with previous aspects of the analysis, two cases are evaluated: one assumes monthly pass use of 80 rides and the other assumes 40 rides. 
Table 6: Estimated Changes to Fare Revenues and Rides per Year

\begin{tabular}{cccccc}
\hline \multirow{2}{*}{ Elasticity / Condition } & Proposal & Proposal & Proposal & Proposal & Proposal \\
& 1 & 2 & 3 & 4 & 5 \\
\hline
\end{tabular}

a. Changes to Fare Revenues per Year

Pass Use at 80 Bus Trips per Month

Initial Estimate - No change in ridership (Price Elasticity $=\mathbf{0 . 0}$ )

Change (Millions of Dollars)

$7.4 \quad 5.4$

$13 \%$

5.3

$-2.0$

3.7

Change (\%)

$18 \%$

4.8

$11 \%$
5.4
$13 \%$

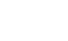

$\begin{array}{ll}0.6 & 3.4 \\ 1 \% & 8 \%\end{array}$

$8 \%$

3.3

4.7
$11 \%$

$-1.9$

$-4 \%$

2.8

$7 \%$

Typical Estimate - Price Elasticity $=\mathbf{- 0 . 3 3}$

Change (Millions of Dollars)

$1 \%$

Pass Use at 40 Bus Trips per Month

Initial Estimate - No change in ridership (Price Elasticity $=0.0)$

\begin{tabular}{lcrrrr} 
Change (Millions of Dollars) & -0.4 & 8.3 & 4.8 & -1.7 & -2.5 \\
$\begin{array}{l}\text { Change (\%) } \\
\text { Conservative Estimate - Price Elasticity }\end{array}$ & $-1 \%$ & $19 \%$ & $11 \%$ & $-4 \%$ & $-6 \%$ \\
$\begin{array}{l}\text { Change (Millions of Dollars) } \\
\text { Change (\%) }\end{array}$ & -0.4 & 7.3 & 4.2 & -1.6 & -2.3 \\
$\begin{array}{l}\text { Typical Estimate - Price Elasticity } \\
\text { Change (Millions of Dollars) }\end{array}$ & $-\mathbf{- 0 . 3 3}$ & $17 \%$ & $10 \%$ & $-4 \%$ & $-5 \%$ \\
Change (\%) & -0.5 & 5.0 & 3.0 & -1.3 & -1.8 \\
\hline
\end{tabular}

\section{b. Changes in Rides per Year ${ }^{1}$}

\begin{tabular}{|c|c|c|c|c|c|}
\hline \multicolumn{6}{|c|}{ Pass Use at 80 Bus Trips per Month } \\
\hline 0.00 & - & - & - & - & \\
\hline-0.10 & $(1,261,524)$ & $(819,772)$ & $(761,074)$ & 265,405 & $(640,241)$ \\
\hline-0.33 & $(4,163,030)$ & $(2,705,249)$ & $(2,511,545)$ & 875,837 & $(2,112,795)$ \\
\hline \multicolumn{6}{|c|}{ Pass Use at 40 Bus Trips per Month } \\
\hline 0.00 & - & - & - & - & \\
\hline-0.10 & $(210,645)$ & $(1,316,572)$ & $(600,234)$ & 213,978 & 134,697 \\
\hline-0.33 & $(695,130)$ & $(4,344,688)$ & $(1,980,771)$ & 706,126 & 444,501 \\
\hline
\end{tabular}

${ }^{1}$ A ride on average system wide includes 1.75 travel legs on a one-way trip. 
Revenues under Proposals 1 and 5 shrink substantially when price elasticity is considered. This follows from the changes in ridership occurring because of drastic rises in fares for many users which offset the benefits of cuts in fares for others. The drop in revenues reflects the loss of patrons who previously used passes or made many transfers to complete their trips vis-à-vis the increase in ridership at the single fare rate. Thus, revenues under Proposal 5 are only half as much as under Proposal 1 with little or no user response. Projected revenues are as volatile in range as to depict them as the most risky options, with the highest increase if ridership unrealistically remained the same to minimal (1\%) gain under typical rider responses. Indeed, revenue is lost under all user responses under the case of low typical pass use per month of 40 rides rather than the high use of 80 rides.

\section{Revenue from Proposal 2: "Raise fares and transfer fees"}

Proposal 2 has similar cost impacts as Proposal 3, but significant differential impacts on riders who make multiple-leg trips produce similar revenues as the latter under high pass use. Under low pass use, it still produces low volatility in revenues with changes in user response, but total revenues are higher. This is consistent with the relatively inelastic nature of transit fares: a percentage increase in fares results in less than proportional decrease in rides resulting in higher revenues overall in the short run. The high use case entails a much smaller unit fare per ride than the low use case. This fact, combined with the inelastic characteristic, produces higher total revenues under the low use case.

\section{Revenue from Proposal 3: "Raise fares with free transfers"}

Proposal 3, with the most neutral cost impacts across user groups, is seen to be less affected by losses in ridership than Proposals 1 and 5. Under the case of high pass use, it shows the potential of increasing revenues substantially and on par with Proposal 2, but with fewer equity implications. The sensitivity analysis reveals that Proposal 3 will also produce the most stable increases in revenue, ranging from $\$ 5$ million to $\$ 3$ million per year, despite the level of pass use.

\section{Revenue from Proposal 4 "Retain existing structure and add weekly pass"}

Proposal 4 is nearly the same as the existing fare structure, but replaces the 10-ride ticket with a pass at similar cost. It adds another source of convenience for the riding public, but at the cost of revenue loss for AC Transit under all user responses.

\section{CONCLUSIONS}

This case study of possible fare policy changes shows the usefulness of on-board survey data in equity and revenue analyses. Information on user characteristics and travel habits is essential for a few reasons. First, it helps to identify users' social and demographic characteristics and to assess the impacts of fare proposals on the various groups they represent. Then it helps in the estimation of how riders would behave when faced with different fare policies. Their responses to proposals ultimately affect agency revenues. The AC Transit case revealed that certain price policies might look like simplifications, as in the pay-per-boarding proposals, but could be both quite inequitable and risky in revenue yield if trip-maker characteristics and tendencies are not taken into consideration.

The study also shows the importance of considering network topography and transfer policies and their interaction with social and economic groups. For the AC Transit case, stratification of the data by local and transbay service provided a refinement to the analysis as it helped capture differences in fare structures and traveler characteristics. The survey data revealed that transfers 
were far more predominant among low income groups than among the more affluent. Therefore, policies that increased the cost of multi-ride trips disproportionately affect the low income. In addition, the data revealed that low income travelers, youth, and the disabled were more likely to use unlimited ride passes than the affluent bus users of the district. Hence, policies that reduced pass availability were again more likely to fall heavily on the low income.

The following observations are noteworthy with respect to specific fare policy proposals:

(a) Proposals 1 and 5, which eliminate passes and transfers, have the least favorable and highly regressive cost impacts on patrons who transfer often. Its impacts are disproportionately higher on youth, low-income earners, and minority groups in comparison with the general impact on all patrons. Revenues under Proposals 1 and 5 shrink substantially when price elasticity is considered with the highest increase if ridership unrealistically remained the same to minimal under typical rider responses. Projected revenues depict as much volatility under varied user responses to make them risky options to pursue.

(b) Proposal 2 is similar to Proposal 3, but involves a lower fare hike and includes a transfer fee hike. Across most subgroups, the distribution of impacts is fairly flat. Differential impacts occur for riders who make multiple-leg trips, making it a little less equitable than Proposal 3. It produces low volatility in revenues with changes in user response, and total revenues are slightly higher than for Proposal 3.

(c) Proposal 3 features the highest base fare hike, but with two free transfers. It is neutral or slightly progressive in its impacts across income groups, making it the most favorable alternative proposal from an equity perspective. Riders who make multiple transfers, many of whom are also low income and minority, fare better under this than other proposals. The segments of riders most severely impacted, single-ride local trip makers and transbay travelers, would be affected relatively uniformly. It shows the potential of increasing revenues substantially, but with fewer equity implications. The sensitivity analysis reveals that Proposal 3 will also produce the most stable increases in revenue regardless of user response.

(d) Proposal 4 is nearly the same as the existing fare structure, but replaces the 10-ride ticket with a pass at similar cost. It adds another source of convenience for the riding public, but at the cost of revenue loss for AC Transit under all user responses.

An analysis, such as presented in this paper, can illuminate the potential equity and revenue impacts of the never ending stream of suggestions that are put forward in times of fiscal difficulty. A board member of AC Transit confirmed that the board relied on the findings of this study in arriving at their decision on a fare change policy (H.E. Christian Peeples, Transportation Research Board Meetings 2006). Review of the existing AC Transit fare structure, which has been in effect since September 1, 2005, reveals that the agency adopted Proposal 2 (see http://www.actransit.org/ riderinfo/busfares.wu), but without an increase in transfer fees. This modification addresses the equity-related drawback of this policy noted as differential impacts on riders who make multipleleg trips. The choice is one of the two most equitable and demonstrated to yield stable, positive revenues. While the specific findings would vary by transit district, the methodology shown here should be broadly applicable.

Finally, it is worth noting that this analysis is based on price elasticity of demand in which rider response is only due to the change in the price of travel on public transit. Cross-elastic effects can result in the shifting of mode choice to public transit, as is observable in recent times, due to the increases in the cost of driving. Such shifts can further increase ridership and net revenues above the estimates from the analytic procedure presented in this paper as long as additions to operating costs necessitated by demand do not offset the revenue gains. 


\section{References}

Altshuler, Alan. The Urban Transportation System: Politics and Policy Innovation. The MIT Press, Cambridge, Massachusetts, 1979.

Ballou, Donald P. and Lakshmi Mohan. Evaluation of Ridership, Revenue and Equity Implications of Distance-Based Fares for Transit Systems. School of Business, State University of New York, Albany, 1979.

Blash, Lisel Monique Nakagawa and John Rogers. 2002 On-Board Passenger Survey: System-wide Results. Prepared for Alameda-Contra Costa Transit District by the Public Policy Research Institute, San Francisco, September 2003.

Cervero, Robert B., Martin Wachs, Renee Berlin and Rex J. Gephart. Efficiency and Equity Implications of Alternative Transit Fare Policies. School of Architecture and Urban Planning, University of California, Los Angeles, 1980.

Curtin, J., "Effects of Fares on Transit Riding." Highway Research Record 213, (1968): 8-18.

De Leuw, Cather and Company. Evaluation of the Trenton Off-Peak Fare-Free Transit Demonstration. New York, NY, 1979a.

De Leuw, Cather and Company. Evaluation of the Denver RTD Off-Peak Fare-Free Transit Demonstration. San Francisco, CA, 1979 b.

Deakin, Elizabeth and Greig Harvey. Transportation Pricing Strategies for California: An Assessment of Congestion, Emissions, Energy and Equity Impacts. Final Report; California Air Resources Board, Sacramento, CA, 1996.

Deakin, Elizabeth, Christopher Ferrell, Jonathan Mason, and John Thomas. "Policies and Practices for Cost effective Transit Investments," Transportation Research Record 1799, (2002).

Fauconnier, Isabelle. "The Privatization of Residential Water Supply and Sanitation Services: Social Equity Issues in the California and International Contexts." Berkeley Planning Journal, Department of City and Regional Planning, University of California, Berkeley, Volume 13, 1998-1999.

Friedman, Lee S. The Microeconomics of Public Policy Analysis. Princeton University Press, Princeton, NJ, 2002.

Garcia, Robert. Transportation Equity in Los Angeles, The MTA and Beyond. Environmental Defense Fund, 1998.

Garrett, M and Brian Taylor. "Reconsidering Social Equity in Public Transit.” Berkeley Planning Journal, Department of City and Regional Planning, University of California, Berkeley, Volume 13, (1998-1999).

Howe, Charles W. "Water Resources Planning in a Federation of States: Equity versus Efficiency," Natural Resource Journal 36, (1996): 29-36.

Linsalata, J. and L.H. Pham. Fare Elasticity and Its Application to Forecasting Transit Demand. American Public Transit Association, Washington, D.C., 1991.

Litman, Todd. "Using Road Pricing Revenue: Economic Efficiency and Equity Considerations." Transportation Research Record No. 1558, Nov. 1996. 
Transit Fare Proposals

Mayworm, P. D., A.M. Lago, and J.M. McEnroe. Patronage Impacts of Changes in Transit Fares and Services. Urban Mass Transportation Administration, Ecosometrics, Incorporated, Bethesda, MD (1980).

Miller, S.M. and Pamela Roby. The Future of Inequality. Basic Books, New York, 1970.

Parody, T. A. Atlanta Integrated Fare Collection: Demonstration Report. For Urban Mass Transportation Administration, By Charles River Associates, Boston, MA, 1982.

Pratt, R. Traveler Response to Transportation System Changes. Transit Cooperative Research Program, Transportation Research Board. Washington, D.C. March 2000.

Rawls, John. A Theory of Justice. Belknap Press of Harvard University Press, Cambridge, MA, 1971.

Richardson, Harry W. and Chang-Hee Christine Bae "The Equity Impacts of Road Congestion Pricing." Road Pricing, Traffic Congestion and the Environment: Issues of Efficiency and Social Feasibility, Edward Elgar, Cheltenham, U.K.; Northampton, MA, c1998.

Small, Kenneth A. and Clifford Winston. "The Demand for Transportation: Models and Applications." J. Gómez-Ibáñez, W. Tye, and C. Winston, eds. Essays in Transportation Economics and Policy: A Handbook in Honor of John R. Meyer. Washington, D.C.: Brookings Institution Press, Chapter 2, (1999): 11-55.

Taylor, Brian D. "Unjust Equity: An Examination of California's Transportation Development Act." Transportation Research Record No. 1297, 1991.

Transit Cooperative Research Program. Traveler Response to Transportation System Changes: Interim Handbook, Transportation Research Board National Research Council, TCRP Project B-12, Washington, D.C., March, 2000.

Transit Cooperative Research Program. Traveler Fare Policies, Structures and Technologies: Update. Transportation Research Board National Research Council, TCRP Report 94, Washington, D.C., 2003; prepared by Multisystems, Inc., Mundle \& Associates, Inc., and Simon \& Simon Research and Associates, Inc, Sponsored by Federal Transit Administration and Transit Development Corporation, accessible online at: http://trb.org/publications/tcrp/tcrp_rpt_94.pdf.

Tsur, Yacov and Ariel Dinar. Efficiency and Equity Considerations in Pricing and Allocating Irrigation Water. World Bank, Agriculture and Natural Resources Dept., Agricultural Policies Division, 1995.

Wachs, Martin. "Improving Efficiency in Transit Finance." The Brookings Institution Series on Transportation Reform, Brookings Institution Press, 2003.

Watkins, Therese Marie. “The Equity Impacts of Time-of-Day Transit Pricing.” Ph.D. Dissertation, University of California, Berkeley. Department of City and Regional Planning.1984. 
Cornelius Nuworsoo is assistant professor of transportation planning at the California Polytechnic State University in San Luis Obispo. Prior to that he was a researcher with the University of California Transportation Center at U.C. Berkeley. He earned a Ph.D. in transportation engineering from U.C. Berkeley in 2004. He has 20 years of field experience spanning multi-modal transportation planning and traffic engineering.

Elizabeth Deakin is professor of city and regional planning at the University of California Berkeley. She is also director of the statewide Transportation Center (UCTC) and co-director of the interdisciplinary Global Metropolitan Studies Initiative at Berkeley.

Aaron Golub is assistant professor of transportation planning at the Arizona State University. Tempe. Prior to that he was a researcher with the University of California Transportation Center at U.C. Berkeley. He earned a Ph.D. in transportation engineering from U.C. Berkeley in 2003. 